\title{
DEPRESI MEMPENGARUHI KINERJA
}

(Sebuah Best Practice)

\author{
Edi Sukamto \\ Jurusan Keperawatan Politeknik Kesehatan Kemenkes Kaltim \\ Jalan Wolter Monginsidi No.38 Samarinda Kalimantan Timur 75123 \\ Email : edidiharjo@yahoo.com
}

\section{A. Pendahuluan}

Kata Depresi sudah sangat popular di telinga masyarakat kita, namun pemahaman masyarakat tentang tanda dan gejala serta upaya pencegahan dan penganan dari Depresi tersebut masih sangat rendah. Katzenstein, L. dan Cass, H. (1998, dalam Hawari, 2011) mengemukakan bahwa 1 dari 5 orang, pernah mengalami depresi dalam kehidupannya. Selain itu, ditemukan pula $5-15$ persen dari pasien-pasien depresi melakukan bunuh diri setiap tahun dan ditemukan fakta bahwa lebih dari 70 persen pasien depresi, tidak terdiagnosa oleh dokter.

Di Indonesia, berdasarkan Riset Kesehatan Dasar tahun 2018, dengan kelompok umur lebih atau sama dengan 15 tahun, ditemukan fakta angka prevalensi gangguan depresi secara nasional, yaitu 6,1 persen atau sebesar 11.315.500 orang, namun hanya 9 persennya, yang ditangani secara medis dan sebagian besarnya (91 persen) tidak ditangani secara medis. Pendapat Ketua Perhimpunan Dokter Spesialis Kedokteran Jiwa Indonesia (PDSKJI), dr. Eka Viora, Sp.KJ, yang dikutip oleh Tri Apriyani dalam tulisannya yang berjudul Indonesia Darurat Depresi Namun Minim Praktisi (Suara.com, 23 Desember 2019), menyebutkan ada sekitar 15,6 juta penduduk yang mengalami depresi di Indonesia. Angka ini diprediksi akan meningkat pada 2020 karena lonjakan demografis atau peningkatan jumlah penduduk.

Gangguan Depresi bisa terjadi pada siapa saja dan akan mempengaruhi pola Kehidupan Efektif Sehari-hari (KES), bahkan pada kondisi tertentu bisa berujung dengan kematian, karena perilaku bunuh diri akibat keputusasaan yang sangat mendalam tanpa ada solusi, baik dari dalam dirinya maupun dari lingkungan terdekatnya. Dalam dunia pendidikan, depresi yang terjadi pada 
anak sekolah dan mahasiswa, dapat terlihat dari prestasi belajarnya yang menurun. Dalam dunia kerja, karyawan yang mengalami depresi dapat tergambar dari kinerjanya yang rendah, bahkan ibu rumah tangga yang mengalami depresi dapat terdeteksi dengan adanya kegelisahan dan menurun pola KES-nya.

Dari penjelasan di atas, penulis ingin berbagi tentang Depresi dan dinamikanya serta mengangkat studi kasus yang terjadi sebagai referensi untuk deteksi dini dan upaya penanganannya.

\section{B. Sekilas Tentang Depresi}

Dengan merujuk pada berbagai referensi, maka di bawah ini akan diuraikan secara singkat tentang Depresi, seperti sebagai berikut.

\section{Pengertian}

Merujuk pendapat berbagai ahli, maka penulis menyimpulkan Depresi sebagai Gangguan alam perasaan (mood) yang ditandai dengan kesedihan yang mendalam dan berkelanjutan sehingg kegairahan hidup berkurang, yang disebabkan oleh perubahan aktivitas psiko-neuroendokrinologi karena diawali oleh adanya stresor psikososial.

\section{Penyebab}

a. Teori Biologi

1) Genetik

Seseorang dengan posisi dalam keluarga sebagai lapis pertama, misalnya anak, kakak, adik dan orang tua, dengan riwayat keluarga depresi cenderung atau lebih berpeluang 10 persen sampai 15 persen mengalami depresi dibandingkan dengan yang tidak memiliki riwayat keluarga depresi. Kelsoe (2000, dalam Videbeck Sheila L, 2001) menyebutkan bahwa untuk peluang terjadinya depresi, faktor keturunan lebih penting daripada lingkungan tempat individu tersebut dibesarkan. Meskipun sumber lain juga menyebutkan bahwa faktor genetik sebagai penyebab depresi ini masih sering dipertentangkan.

2) Neurokimia

Neurokimia yang bekerjanya dalam proses neurotransmisi, mempengaruhi terjadinya depresi. Asetilkolin (jenis kolinergik) berkontribusi meningkatkan derajat depresi. Selain itu untuk jenis Monoamin seperti norepinefrin dan Serotonin atau Metabolit Serotonin (5HIAA) yang kadarnya rendah 
dalam darah dan cairan serebrospinal, dapat dijumpai pada seseorang yang mengalami depresi.

Di bawah ini adalah bagan terjadinya proses neurotransmisi dari sistem saraf yang satu ke sistem saraf yang lain. (Scanlon and Sanders, 1995 dalam Suliswati dkk, 2005 ; Conway,BA and Rutkowski, 1982 ).

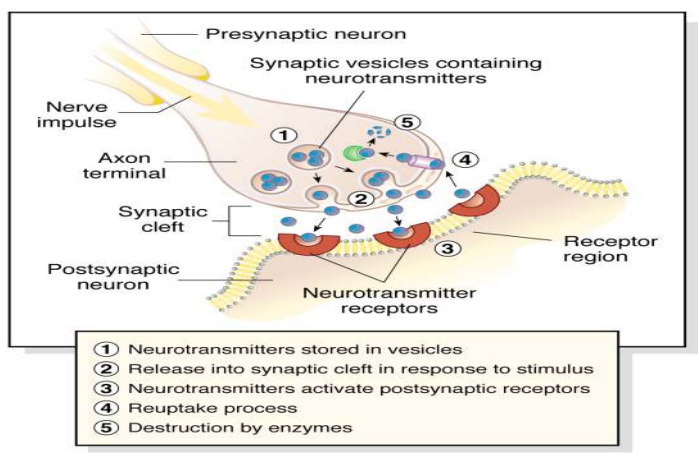

3) Neuroendokrin

Perubahan kadar hormon pascapartum, menyebabkan depresi yang serius. Sindrom mencakup gejala depresi, disertai gejala fisik, seperti retensi air dan pembengkakan payudara.

4) Siklus Biologi

Gangguan afek musiman, di mana depresi terjadi pada seseorang ketika kurang mendapat sinar matahari, sebaliknya jika seseorang mendapatkan sinar matahari yang lebih cukup, maka gejala depresi akan berkurang. Dari siklus biologi inilah menjadi pijakan untuk digunakan terapi sinar cahaya bagi penderita depresi.

b. Teori Psikodinamik

Freud (1917), mengajukan sebuah hipotesis bahwa depresi berawal dari kemarahan yang tidak terkendali akibat pengabaian pada masa bayi karena ibunya meninggal dunia dan terpisah secara emosional atau karena kondisi lainnya. Kehilangan objek yang dicintai ini, menimbulkan rasa tidak aman, kesedihan dan kemarahan. Kehilangan ini terjadi pada fase oral, di mana bayi yang penuh dengan ketergantungan dan belum memiliki konsep tentang individuasi dari orang tua. Saat menjadi dewasa, individu yang berduka, kembali ke fase oral dan mengintroyeksikan kemarahannya tentang pengabaian atau konflik yang tidak selesai pada obyek yang hilang menjadi kemarahan terhadap diri mereka sendiri. Introyeksi adalah suatu mekanisme pertahanan yang tidak disadari, di mana individu menginternalisasi sudut pandang dan nilai-nilai objek yang dicintainya, dengan mengintegrasikan sudut pandang dan nilai-nilai tersebut ke 
dalam identitas dan sistem keyakinannya sendiri.

c. Teori Kognitif

Seseorang yang depresi, menurut Aaron Beck (1967 dan 1976), disebabkan oleh pikiran yang negatif. Mereka memandang diri sendiri, dunia dan masa depan mereka dalam bentuk kegagalan yang menyimpang, dengan secara berulang menginterpretasikan pengalaman sebagai hal yang sulit dan membebani serta menginterpretasikan diri mereka sendiri sebagai orang yang tidak kompeten.

d. Teori Sosial atau Lingkungan

Lingkungan dianggap memiliki pengaruh terhadap depresi. Kehilangan hubungan atau peran hidup yang penting dapat menyebabkan depresi. Kondisi depresi juga sering terjadi karena penganiayaan fisik atau seksual. Boyd and Nihart (1998), menjelaskan kondisi seseorang yang sudah lanjut usia, cenderung akan mengalami depresi karena merasa dirinya terisolasi secara sosial, di samping karena faktor keungan yang sangat terbatas.
3. Gejala dan Tanda Depresi

a. Suasana Perasaan

Munculnya perasaan seperti sedih, murung, kehilangan minat dan rasa senang terhadap pekerjaan yang biasa dilakukan, sering pula mudah tersinggung serta mengalami rasa cemas dan panik bahwa sesuatu yang buruk akan terjadi.

b. Pikiran

Isi pikiran biasanya tentang kegagalan dan kesalahan, cenderung menyalahkan diri sendiri terhadap kegagalan yang terjadi, sulit memusatkan perhatian, daya ingat menjadi terganggu dan kadangkadang timbul pikiran ingin mati.

c. Keluhan Fisik

Merasa lelah berkepanjangan, gangguan tidur (sulit tidur atau terlalu banyak tidur), gangguan makan (tidak nafsu makan atau banyak makan), kehilangan minat seksual, rasa sakit dan nyeri di leher dan punggung, sakit kepala, nyeri di dada dan keluhan di perut serta keluhan fisik lainnya dari ujung rambut sampai ujung kaki.

d. Kegiatan (Aktivitas)

Kegiatannya menjadi menurun, ia hanya berbaring di tempat tidur sepanjang hari atau ia menarik diri 
dari pergaulan. Dalam keadaan seperti ini kadang-kadang ada usaha untuk bunuh diri.

\section{Depresi menurunkan kinerja} (Sebuah Best Pratice)

a. Studi Kasus Pegawai Negeri Sipil

Klien, Ny.M, 50 tahun, beragama Islam, Sarjana, sebagai pegawai negeri sipil di sebuah kantor pemerintah. Pada satu bulan yang lalu, klien dimutasi ke bagian lain, meski berada di kantor yang sama. Sejak itulah klien merasakan susah tidur, kalaupun bisa tidur tapi tidak nyenyak dan sering terbangun, kepala sakit, berdebar-debar, merasa banyak persoalan, mengambang dan tidak berguna, tidak dihargai dan tidak dibutuhkan, tidak bersemangat, mudah bosan, tidak kuat dan tidak sanggup, dalam dirinya merasakan kalau orang lain mengejeknya tidak berkinerja.

b. Studi Kasus Mahasiswa

Klien, Nn. O, 20 tahun, beragama Islam, Mahasiswa di sebuah perguruan tinggi negeri. Klien tinggal di tempat kos, yang mana kedua orangtua dan saudara kandungnya tinggal di luar kota. Sejak dua minggu yang lalu, klien merasakan susah tidur, mimpi buruk, sakit kepala, berdebar-debar, merasa banyak tugas kuliah yang harus dikerjakan, merasa pegal-pegal di sekujur badan, tidak fokus dalam mengikuti perkuliahan, sering nyeri lambung, dalam dirinya merasakan kalau orang lain melihatnya seperti orang yang labil atau melankolis, sering merasakan kesepian karena tinggal berjauhan dengan orang tua.

c. Studi Kasus Siswa

Klien, Nn. S, 16 tahun, beragama Islam, anak kedua dari dua bersaudara. Siswa di sebuah SMA Negeri. Klien tinggal di tempat kakeknya, yang mana kedua orang tuanya bercerai sejak 3 tahun yang lalu. Bapaknya menikah lagi dan tinggal bersama isteri mudanya, sementara Ibunya juga menikah lagi dengan suaminya yang baru. Sejak satu bulan yang lalu, klien merasakan susah tidur, mimpi buruk, sakit kepala, nyeri di bagian tengkuk, sakit punggung, berdebardebar, merasa banyak tugas di sekolah yang harus dikerjakan, merasa pegal-pegal di sekujur badan, meski tidak banyak beraktivitas, tidak fokus dalam mengikuti pelajaran di sekolah, sering nyeri lambung, dalam dirinya merasakan 
mudah sedih atau melankolis, lebihlebih sering memikirkan nasib ibunya yang tinggal di tempat kos bersama suami barunya. Di samping perlakuan sang kakek terhadap klien yang kurang perhatian dan sering mengeluarkan kata-kata yang menyakitkan.

Asuhan Keperawatan yang dilakukan pada klien di atas adalah.

1. Setelah terjalin hubungan saling percaya (trust), klien diberi kesempatan untuk memventilasi perasaannya dan mengungkapkan harapan-harapannya.

2. Latihan Tarik Nafas Dalam (Deep breathing Exercise), dengan tujuan agar klien lebih tenang atau rileks.

3. Klien didampingi untuk menyusun rencana kegiatan yang terukur dalam 24 jam dan menjalankan rencana kegiatan tersebut, dengan tujuan agar Kehidupan Efektif Sehari-hari (KES) klien dapat meningkat.

4. Klien didampingi untuk mengeksplor potensi dirinya (hal-hal bersifat positif) yang ada dalam dirinya, dengan tujuan akan meningkatkan kesadaran dirinya sehingga menjadi lebih bersemangat atau meningkat harapan-harapan masa depannya, serta mampu mengadaptasi dinamika yang terjadi di tempat kuliahnya.

5. Libatkan keluarga untuk mendampingi klien, agar masalah yang dihadapinya bisa segera terselesaikan.

6. Jika kondisi masih berlangsung dan belum ada perubahan yang bermakna, bisa dirujuk pada dokter spesialis jiwa (psikiater).

\section{Penutup}

Dari ketiga kasus di atas, dapatlah disimpulkan bahwa, ketika seseorang mengalami depresi dalam status apapun, maka akan berdampak pada kehidupan efektif sehari-harinya, yang pada gilirannya tugas pada suatu jabatan atau status tertentu tersebut akan berkinerja tidak sesuai dengan yang seharusnya diinginkan oleh atasannya atau organisasi di mana dia bekerja.

\section{Daftar Pustaka}

Conway, BA and Rutkowski (1982 ) Neurological and Neurosurgical Nursing eighth edition, St. Louis Missouri, C.v. Mosby Company

Hawari, D. (2011) Manajemen Stres Cemas dan Depresi, edisi ke-2, cetakan ke-3, Jakarta, Balai Penerbit FKUI

Knesil et al (2004), Contemporary Psychiatric Mental Health Nursing, Upper Saddle River New Jersey, Pearson Education Inc. 
Mahakam Nursing Journal Vol 2, No. 7, Mei 2020 : 298 - 304

Levy Marvin R et al (1984), Life \& Health, Fourth Edition, New York, Random House Inc.

Kemenkes, RI ( 2018) Riset Kesehatan Dasar

Suliswati, dkk. (2005), Konsep Dasar Keperawatan Kesehatan Jiwa, cetakan I, Jakarta, Penerbit BukuKedokteran EGC
Videbeck Sheila L , (2001) Psychiatric Mental Health Nursing ( Edisi terjemahan, Cetakan I, 2008, Jakarta, EGC.

Wilkinson, G. (1995), Depresi edisi terjemahan cetakan II, Jakarta, Arca. 